\title{
Growing evening primroses (Oenothera)
}

\section{Stephan Greiner* and Karin Köhl}

Max Planck Institute of Molecular Plant Physiology, Potsdam, Germany

\section{Edited by:}

Rina Kamenetsky, Agricultural

Research Organization-The Volcani

Center, Israel

\section{Reviewed by:}

Juan B. Alvarez, Universidad de Córdoba, Spain

Monique Bodson, University of Liège, Belgium

\section{*Correspondence:}

Stephan Greiner, Max Planck Institute of Molecular Plant Physiology, Wissenschaftspark Golm, Am Mühlenberg 1, 14476 Potsdam-Golm, Germany

e-mail: greiner@mpimp-golm.mpg.de
The model plant Oenothera has contributed significantly to the biological sciences and it dominated the early development of plant genetics, cytogenetics, and evolutionary biology. The great advantage of using Oenothera as a model system is a large body of genetic, cytological, morphological, and ecological information collected over more than a century. The Oenothera system offers a well-studied taxonomy, population structure, and ecology. Cytogenetics and formal genetics at the population level are extensively developed, providing an excellent basis to study evolutionary questions. Further, Oenothera is grown as an oil seed crop for the production of essential fatty acids (gamma-linoleic acid) and is considered to be a medicinal plant due to its many pharmaceutically active secondary metabolites, such as ellagitannins. Although Oenothera has been cultivated as a laboratory organism since the end of the 19th century, there is a substantial lack of literature dealing with modern greenhouse techniques for the genus. This review compiles an overview about the growth requirements for the genus Oenothera, with a special focus on its genetically best-studied subsections Oenothera and Munzia. Requirements for greenhouse, field, and agronomic cultures are presented, together with information on substrate types, pest control, as well as vegetative and seed propagation, cross pollination, harvest, and seed storage. Particular aspects like germination, bolting, and flowering induction in taxonomically diverse material are reviewed. Methods recommended are supported by ecological and experimental data. An overview of the possibilities for wide hybridization and polyploidy induction in the genus is given. Germplasm resources are referenced. In summary, a comprehensive guideline for successful laboratory cultivation of Oenothera species is provided.

Keywords: Oenothera, evening primrose, experimental culture, growth requirements, propagation, pest control

\section{INTRODUCTION}

The first reports on growing Oenothera (evening primrose, Onagraceae) coincide with the early rise of genetics. For example, pioneering work on Oenothera led Hugo de Vries to the formulation of his mutation theory (de Vries, 1901-1903; Nei and Nozawa, 2011), and evening primroses dominated classical cytoplasmic genetics (Chiu and Sears, 1993; Harte, 1994; Hagemann, 2010; Johnson, 2010). At the same time, the genus became a notable model to study non-Mendelian inheritance, plastome-genome co-evolution, cytoplasmic elements in plant adaptation and speciation, suppression of genome-wide recombination, chromosome translocations, and evolutionary ecology (Golczyk etal., 2008; Greiner etal., 2008; Rauwolf etal., 2008; Johnson et al., 2009b; Artz et al., 2010; Johnson, 2010; Theiss et al., 2010; Brown and Levin, 2011; Evans et al., 2011; Greiner etal., 2011; Rauwolf etal., 2011; Agrawal et al., 2012; Greiner, 2012; von Arx etal., 2012; Burton etal., 2013; Greiner and Bock, 2013). Furthermore, Oenothera is exploited as a crop for the production of the essential gamma-linoleic fatty acid (Deng et al., 2001; Fieldsend, 2007). Many of its secondary metabolites, such as ellagitannins (e.g., oenothein B, which suppresses tumor development), are of increasing importance (for references, see Singh et al., 2012).

Although research on Oenothera has been conducted for more than 120 years, there are only a few summaries available describing cultivation techniques for evening primrose as a laboratory organism. Relevant information was either published very early in the German literature, or was never published but passed on within schools of Oenothera workers. Most of these methods, however, only refer to field experiments and almost no reports cover modern greenhouse cultivation. This is in sharp contrast to a substantial and emerging literature describing crop management of Oenothera in agronomics. The aim of the present work is to summarize published and unpublished methods used by generations of Oenothera researchers. In addition, methods for greenhouse cultivation, developed at the Ludwig-Maximilians-University in Munich, Germany, as well as the Max Planck Institute of Molecular Plant Physiology, Potsdam-Golm, Germany, are presented. All methods are set into an ecological context and a summary of the comprehensive experimental literature supporting these methods is given.

Currently, the genus Oenothera consists of 145 species subdivided into 18 sections $^{1}$. It colonizes a wide range of habitats and climate zones. Although originated in the Americas, some of its species easily adapt and the genus includes nearly cosmopolitan but also endemic taxa (Wagner et al., 2007). This results in a huge diversification, e.g., in the requirements for flower

\footnotetext{
${ }^{1}$ Sections and subsections are taxonomic ranks below the genus level, used if appropriated in plant taxonomy.
} 
induction, which can vary even within a species (e.g., Evans et al., 2005; Johnson, 2007; and references therein). Hence, the synchronization of large numbers of Oenothera cultivars containing multiple genotypes is challenging. Protocols described in this work are based on approaches developed for the wellstudied section Oenothera, that currently contains 65 species in the six subsections Oenothera, Raimannia, Munzia, Candela, Emersonia, and Nutantigemma (Wagner et al., 2007). Among them, genetically most important are subsection Oenothera (syn: Euoenothera; Dietrich et al., 1997) and species formally grouped into the sections/subsections Raimannia, Renneria, Anogra, and Eu-Oenothera. The genetically studied material of the latter groups is now included within section Kleinia and subsections Munzia and Candela (Dietrich, 1977; Dietrich and Wagner, 1988; Wagner etal., 2007). Extensive genetic literature exists for this material (for review, see Cleland, 1972; Harte, 1994). For subsection Oenothera, detailed physiological studies have facilitated the development of growth protocols, with the original methods referring to the subsections Oenothera and Munzia (de Vries, 1913; Schwemmle et al., 1938). These methods can, however, be used for the whole section Oenothera (cf., Stubbe and Raven, 1979a) and for material from other sections, like Oenothera cespitosa (section Pachylophus), Oe. speciosa (section Hartmannia), or Oe. macrocarpa (section Megapterium). The protocols may apply thus to most Oenothera species, even if specific culture recommendations given in this work largely refer to the subsection Oenothera and the genetic stocks of Julius Schwemmle and co-workers (subsection Munzia).

\section{GENERAL CHARACTERISTICS}

Oenothera is an herbaceous plant. Species of subsection Oenothera are facultative biennials or short-lived perennials, $40 \mathrm{~cm}-2.5 \mathrm{~m}$ $(4.0 \mathrm{~m})$ in size with typical heights of $1.0-1.5 \mathrm{~m}$. Rosette size can vary between 10 and $40 \mathrm{~cm}$, reaching the upper limit when cultivated (Figures 1C,D). Subsection Munzia is annual or biennial, with a huge height variation, from a few $\mathrm{cms}$ to $2.0 \mathrm{~m}$ with rosette diameters of 5-70 cm (Dietrich, 1977; Hall et al., 1988; Harte, 1994; Dietrich etal., 1997; Wagner et al., 2007). Many diploid species in the genus are permanent translocation heterozygotes, i.e., due to reciprocal chromosome translocations meiotic rings are formed. This leads to formation of two superlinkage groups, so called Renner complexes, each involving one complete haploid chromosome set ( $\alpha$ and $\beta$ ). Specialized breeding behavior, e.g., gametophytic lethal factors, can eliminate homozygous segregants $(\alpha \cdot \alpha$ or $\beta \cdot \beta)$, resulting in permanent heterozygous offspring $(\alpha \cdot \beta)$ only (Cleland, 1972). Within subsection Oenothera, three basic nuclear genomes $(A, B$, and $C$ ) occurring in homozygous (AA, BB, and $\mathrm{CC}$ ) or stable heterozygous ( $\mathrm{AB}, \mathrm{AC}$, and $\mathrm{BC})$ combinations could be identified. These are associated with five basic plastome (chloroplast genome) types (I-V). Combinations of distinct basic nuclear genomes with basic plastome types represent an important factor in species definition (Stubbe, 1989; Dietrich et al., 1997).

\section{GENERAL CULTIVATION SCHEME IN THE GREENHOUSE}

Oenothera is a robust plant and can be grown easily in the greenhouse or in field plots in temperate regions, although not all taxa
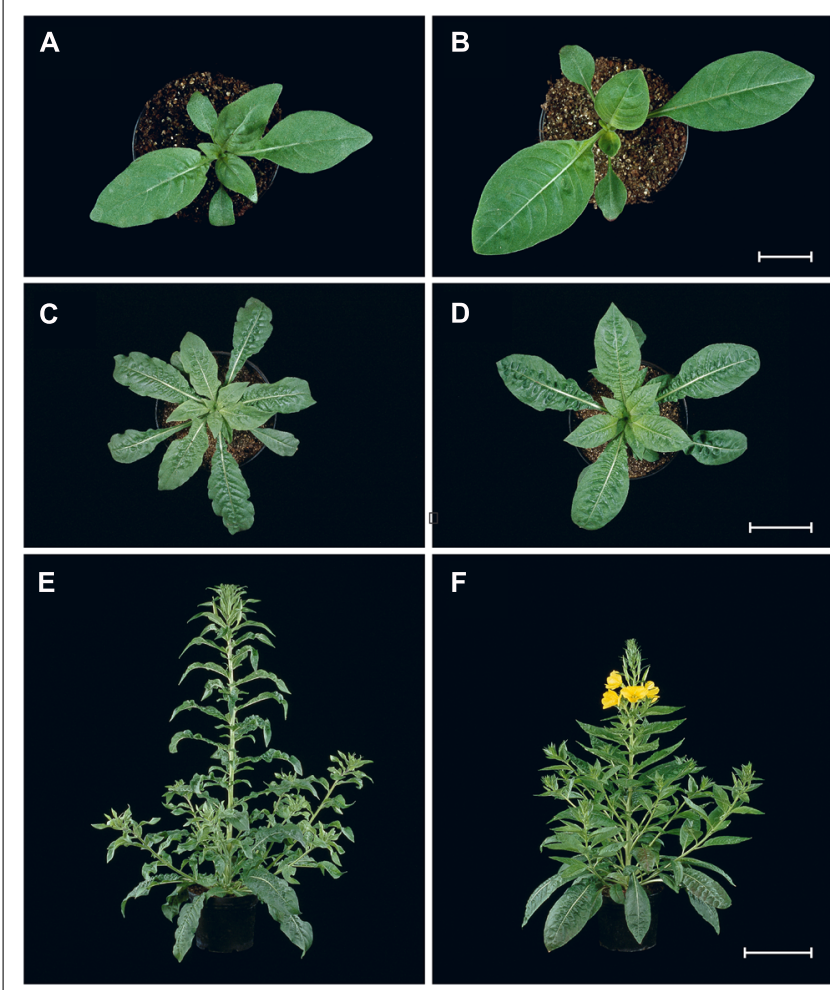

FIGURE 1 | Developmental series of plants from subsection Oenothera under controlled greenhouse conditions. Oe. elata $(\mathbf{A}, \mathbf{C}, \mathbf{E})$, Oe. biennis (B,D,F). Beginning of early rosette stage, 21 days after germinations (A,B). Bar: $2 \mathrm{~cm}$. Note variation in leaf number and size between the two species. Mature rosettes just before bolting, 42 days after germination (C,D). Bar: 10 $\mathrm{cm}$. Mature plants, 77 days after germination (E,F). Bar: $20 \mathrm{~cm}$. Oe. biennis already starts blooming (F), whereas Oe. elata will flower in approximately 1 week (E)

are equally well suited for both venues. Under optimal cultivation conditions, the generation time of Oenothera comprises 4-6 months, depending on the strain. Cultivation times range from around 4 months for the strains of the subsection Munzia and 6 months for species of subsection Oenothera. However, several important laboratory strains in subsection Oenothera complete their life cycle in 5 months.

Long-day conditions (16 h light/8 h dark) are required in all stages of a greenhouse culture, except for vernalization (see below). With the exception of Oe. grandiflora, short-day conditions inhibit flower formation (see below). Standard growth temperatures range from 18 to $22^{\circ} \mathrm{C}$. Higher temperatures such as $24^{\circ} \mathrm{C}$ (Glick and Sears, 1994; Johnson et al., 2009b) are tolerated and can even promote growth. They should, however, not exceed $27^{\circ} \mathrm{C}$ since for example bolting may be prevented (Yaniv et al., 1989; Clough et al., 2001; Giménez et al., 2013; but also see von Arx etal., 2012). Plants start to develop the first true leaves 7-10 days after germination at a plant size of $2.0-2.5 \mathrm{~cm}$ diameter. At this stage, they are transferred from seedling trays to individual pots. About 3-4 weeks after germination, plants reach the early rosette stage with a diameter of about $12 \mathrm{~cm}$ and develop the 5th and 6th leaves (Figures 1A,B). Depending 
on the line, the stage corresponds approximately to stage 1.5 in the Oenothera developmental code developed by Simpson (1994). This is the earliest stage, in which plants can be vernalized and transplanted into the final pots of $18 \mathrm{~cm}$ for greenhouse cultivation or alternatively into field plots (see below). However, also bigger and stronger plants can be used for transplanting in field cultures. Hence, vernalization and transplanting at later stages is possible, but plants should not be kept too long in $6 \mathrm{~cm}$ pots, since they become pot-bound or crowd each other. After transplanting, a burst of growth is observed. Depending on the strain/species, bolting starts 6-8 weeks and flowering 10-15 weeks after germination (cf., de Vries, 1913; Figures 1C-F). Subsection Munzia develops faster. With the exception of Oe. grandiflora, which bolts very earlier and but might need special treatments for flower induction (see below), flowering always follows bolting. Seed ripening requires another four (subsection Munzia) to eight weeks. Fresh seeds can be sown immediately after harvest (cf., Steiner, 1968; Baskin and Baskin, 1994). In the field, the plant dies after completing its life cycle (Hall et al., 1988; Dietrich etal., 1997). However, also iteroparous behavior, i.e., flowering in two subsequent field seasons has been reported, especially for sandy habitats with moderate plant density (Johnson, 2007). In general, production of successive flowers depends on day-length and terminates in short-day conditions, i.e., at the end of a field season but not in long-day greenhouse conditions. For growth schemes of Oenothera cultures under various conditions see, e.g., Kachi and Hirose (1983); Gross and Kromer (1986), Russell (1988); Reekie and Reekie (1991), Fieldsend and Morison (2000b); Clough et al. (2001), Deng et al. (2001); Fieldsend (2004), Honermeier et al. (2005), Vilela et al. (2008), or Giménez et al. (2013).

\section{SUBSTRATE TYPES AND IRRIGATION}

Oenothera can be grown on a range of substrates. However, as a ruderal, calcicoles weed occurring on sandy or gravelly soils (Hall et al., 1988; Dietrich et al., 1997), it prefers well-drained substrates, tolerates low nutrient contents (cf., de Vries, 1913) and moderate watering. Nevertheless, the plant has a high water demand during bolting, when it grows rapidly. To achieve optimal results, plants must be fertilized. In ecological field studies, the largest biomass and seed production were observed in tilled fields with rich soils (Johnson and Agrawal, 2005; Johnson, 2007; Johnson et al., 2008).

At the Max Planck Institute in Golm, seeds were germinated on and transferred to peat-based commercial substrates optimized for Arabidopsis growth (e.g., MPG-mixture from Stender AG, Luckenwalde, Germany) that contain fibric peat, vermiculite, and sand [7:2:1], supplied with $150 \mathrm{mg} / \mathrm{l}$ microelements, $100 \mathrm{mg} / \mathrm{l}$ Fe-chelate and $1 \mathrm{~g} / \mathrm{l}$ of the slow-release NPK-fertilizer "Osmocote Start" (Everris International B.V., The Netherlands). Older plants were transferred to "Oenothera substrate," a mixture of the peat-based substrate "Standard Potting Soil Classic," quartz sand, and fine-grained vermiculite [4:2:1], supplied with $3 \mathrm{~g} / \mathrm{l}$ "Osmocote Exact Standard 3-4 M" (Everris International B.V., The Netherlands). "Standard Potting Soil Classic" is a soil mixture supplied by the company Einheitserde- und Humuswerke Gebrüder Patzer GmbH \& Co.KG, Sinntal/Altengronau, Germany. It is composed of natural clay, fibric and sod peat, supplemented with 250-450 mg/l nitrogen, 250-450 mg/l $\mathrm{P}_{2} \mathrm{O}_{2}$, as well as $\mathrm{K}_{2} \mathrm{O}(360-500 \mathrm{mg} / \mathrm{l}$ ) at pH 6.0 (Köhl, unpublished; Table 1).

In the laboratory of Wilfried Stubbe, Peat Culture Substrate 1 was used up to the early rosette stage and Peat Culture Substrate 2, a soil mix with higher fertilizer concentration, for successive cultivation (Linne von Berg, 1990). Substrates used by the laboratory of Marc T. J. Johnson include Sunshine Mix 1 or Pro Mix General Purpose Peat Soil with vermiculate and a balanced Osmocote [13:13:13], sometimes with micronutrients (e.g., Johnson et al., 2009b).

\section{GERMINATION}

Germination of Oenothera seeds requires light and moisture. Seeds are therefore sown on the substrate surface and covered with a translucent dome to maintain humidity. Seedlings appear after one or two weeks. With this method, seed quality, age and/or strain can affect germination capacity and rate substantially up to the point of extreme delays. Large difference can be observed even between different sowings of the same seed lot (Davis, 1915; de Vries, 1915). Germination rates and synchronization can be increased by soaking seeds for $24 \mathrm{~h}$ at low temperatures $\left(4-10^{\circ} \mathrm{C}\right)$ in the dark (cf., Ensminger and Ikuma, 1988). Seeds soaked in $0.1 \%$ Agarose can be spread more easily with a pipette. Reliable complete germination can be achieved by transferring imbibed seeds to continuous light and $28^{\circ} \mathrm{C}$ (cf., Gross, 1985; Ensminger and Ikuma, 1987a).

Since such conditions are difficult to achieve in the greenhouse, seeds should be germinated on wet blotting paper in a petri dish (cf., de Vries, 1913; Davis, 1915; Renner, 1917). More efficiently, the seeds can be placed on a wet filter paper, which is placed on the wall of a glass beaker or vial with a lid. The moisture of the paper is maintained by covering the bottom of the beaker with tap water and dipping the filter paper into it (Figure 2). In this system, seeds germinate completely within 1-3 days (de Vries, 1915, 1916, 1917). If germination is delayed, fungi may appear on the seeds and filter paper, which requires rinsing seeds with a 3\% hydrogen peroxide solution (Linne von Berg, 1990). Low quality seed lots from sub-optimal storage or of increased age (see below) require surface-sterilization with hypochlorite. These seeds can be sown on sterile filter paper (Zupok, unpublished) or on sucrose free 1/2 MS medium (cf., Chiu et al., 1988; de Gyves et al., 2001). Delayed seed germination can be overcome by pressing water into soaked seeds with 6-8 bar for 2-3 days (de Vries, 1915), or by repeated incubation at $10-15^{\circ} \mathrm{C}$ for the same timeframe. Subsequently, seeds must be returned to higher temperatures (Renner, 1917). Likewise, wetting/drying cycles, stratification, and exposure to hot temperatures can break dormancy. In commercial cultures, soaking at $45-50^{\circ} \mathrm{C}$ for $24-48 \mathrm{~h}$, or early spring burial in frozen soils is sometimes applied to promote germination. Other methods, to improve germination rates such as application of sulfuric acid, abrasion, or priming, do not give satisfactory results (for references, see de Vries, 1915; Steiner, 1968; Hall et al., 1988; Nightingale and Baker, 1995; Deng et al., 2001; Wees, 2004; Xu et al., 2010).

Interestingly, light quality has an influence on germination (Gross, 1985). Best germination results are obtained in the spring, 
Table 1 | Cultivation conditions for Oenothera in climate controlled glasshouses or foil greenhouses without heating/cooling.

\begin{tabular}{|c|c|c|}
\hline Working step & Controlled environment & Foil greenhouse \\
\hline \multicolumn{3}{|l|}{ Sowing } \\
\hline Container (internal dimension) & Seed flat $(50 \mathrm{~cm} \times 32 \mathrm{~cm}$, depth $6 \mathrm{~cm})$ & $\begin{array}{l}\text { Storage container with perforated bottom }(35.5 \mathrm{~cm} \times 25.5 \mathrm{~cm} \text {, } \\
\text { depth } 10.5 \mathrm{~cm})\end{array}$ \\
\hline Substrate & Stender MPG-mixture for Arabidopsis thaliana ${ }^{1}$ & Stender MPG-mixture for Arabidopsis thaliana ${ }^{1}$ \\
\hline Fertilizer & None & None \\
\hline Plants per container & 50-100 seeds & $50-100$ seeds \\
\hline \multicolumn{3}{|l|}{ Transferring } \\
\hline Time $(\text { das })^{2}$ & $14-21$ & $14-21$ \\
\hline Container (dimension) & Round $6 \mathrm{~cm}$ pot & Round $10 \mathrm{~cm}$ pot \\
\hline Substrate & Stender MPG-mixture for Arabidopsis thaliana ${ }^{1}$ & Oenothera substrate ${ }^{3}$ \\
\hline Fertilizer & $1 \mathrm{~g}$ Osmocote start/l substrate & $3 \mathrm{~g} / \mathrm{l}$ Osmocote Exact Standard 3-4 M \\
\hline Plants per container & 1 & 1 \\
\hline
\end{tabular}

\section{Planting}

Time $(\text { das })^{2}$

40-50

Container (dimension)

Round 18-cm pots (diameter $17.5 \mathrm{~cm}$, height

$16.5 \mathrm{~cm})$

Substrate

Fertilizer

Plants per container

\section{Oenothera substrate 3}

$3 \mathrm{~g} / \mathrm{l}$ Osmocote Exact Standard 3-4 M

1

\section{$40-50$}

Round 18-cm pots (diameter $17.5 \mathrm{~cm}$, height $16.5 \mathrm{~cm}$ )

Oenothera substrate ${ }^{3}$

$3 \mathrm{~g} / \mathrm{l}$ Osmocote Exact Standard 3-4 M

1

${ }_{1}^{1}$ Composition of Stender MPG-mixture: fibric peat, vermiculite, and sand [7:2:1], supplied with $150 \mathrm{mg} / \mathrm{l}$ microelements, $100 \mathrm{mg} / \mathrm{l} \mathrm{Fe-chelate.}$

2 Days after sowing.

${ }^{3}$ Composition of Oenothera substrate: peat-based substrate "Standard Potting Soil Classic" (natural clay, fibric and sod peat, supplemented with 250-450 mg/l nitrogen, 250-450 mg/l $\mathrm{P}_{2} \mathrm{O}_{2}$, as well as $\mathrm{K}_{2} \mathrm{O} 360-500 \mathrm{mg} / \mathrm{l}$ at $\mathrm{pH}$ 6.0), quartz sand, and fine-grained vermiculite [4:2:1]). Before sowing or transferring, the substrate is soaked with tap water containing $0.906 \mathrm{mg} / \mathrm{l}$ Propamocarb to prevent damping off.

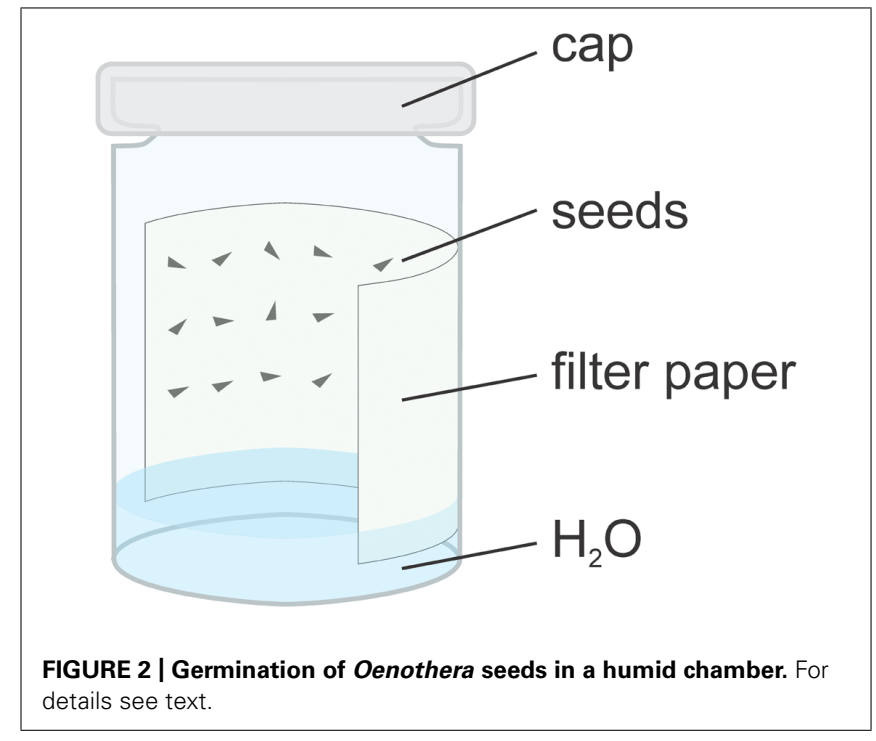

when seeds are exposed to sunlight (cf., Davis, 1915; de Vries, 1917; Linne von Berg, 1990; Johnson and Agrawal, 2005). In general, Oenothera seeds display a seasonal change of dormancy. Germination is regulated by a subtle interplay of temperature and the duration of exposure to a particular temperature, light quality, quantity, time point and length, storage conditions and length, or date of harvest. Also genotypic differences have been recognized. Under certain conditions, light is not even required for germination (Davis, 1915; Fujii and Isikawa, 1961; Schwemmle, 1961; Steiner, 1968; Gross, 1985; Ensminger and Ikuma, 1987a,b; Ensminger and Ikuma, 1988; Baskin and Baskin, 1994; Doroszewski, 2007).

Interesting exceptions from the standard germination protocols are species with fruits that do not dehisce (i.e., section Gaura). Capsules, which only contain one to four (five) seeds (Wagner et al., 2013), are placed in $1 \mathrm{~cm}$ depth into the substrate and exposed to fluorescent white light at regular greenhouse temperatures until seedlings establish. This procedure is required because the seeds are embedded in very hard tissue. 1-2 days of soaking the capsules does help to loosen the carpels, but it is still insufficient to extract the seeds effectively. In soil, the tissue, in which the seeds are embedded, decomposes quickly after a few days (Johnson, unpublished; Hollister et al., submitted).

Germination can be influenced by seed infection with Septoria oenotherae, an Ascomycota species developing pycnidia (asexual fruit bodies) within seeds. The pathogen is ubiquitously present in Oenothera cultures (Simpson et al., 1995; O'Connell et al., 2005). Heavily infected seed lots exhibit reduced or no germination. 
Adding $0.05 \%$ of Plant Preservative Mixture (Plant Cell Technology Store, Washington, DC, USA) to germination media in tissue culture plates, or $3 \%$ of the chemical while soaking the seeds, significantly enhances germination rates (Stegemann et al., unpublished). Incubation of the seeds in $45^{\circ} \mathrm{C}$ hot water for $25 \mathrm{~min}$ destroys the fungus without affecting germination ( $\mathrm{O}^{\prime}$ Connell et al., 2005). Long-term steed storage at $-20^{\circ} \mathrm{C}$ (see below) reduces fungal survival (Greiner, unpublished). Finally, it should be mentioned that in some permanent translocation heterozygous strains $50 \%$ of the seeds are aborted as a consequence of sporophytic lethal factors (cf., Cleland, 1972).

\section{BOLTING AND FLOWER INDUCTION}

Requirements for flower-induction are quite diverse within the whole genus Oenothera, and vernalization response is not uniform within a species. Depending on the material, various kinds of behaviors have been reported. For example, most of the strains of subsection Munzia do not require vernalization when grown in long-day conditions. Oe. grandiflora is described as a short-day species, but flowers under long-day conditions in the greenhouse, but not in the field (Steiner and Stubbe, 1984; Greiner, unpublished; Johnson, unpublished; see below). Some lines can be devernalized in short day (and need long days after vernalization), whereas others are day neutral after vernalization (for reviews and references see Chouard, 1960; Wellensiek, 1965; Steiner and Stubbe, 1984; Takimoto, 1985; Clough et al., 2001; Wilkins and Anderson, 2007).

Many Oenothera taxa, however, are winter annuals or (facultative) biennials (Dietrich, 1977; Hall et al., 1988; Dietrich et al., 1997). In these genotypes, flower induction in the greenhouse requires vernalization followed by a long-day exposure. Alternating cold-warm treatments are more effective than continuous cold (Chouard, 1960; Picard, 1965). Seed vernalization seems to be ineffective (Chouard, 1960; Picard, 1965; but also see Thomas and Vince-Puce, 1997, p. 161; Deng et al., 2001), but some vernalization response was observed in seedlings by Giménez et al. (2013). In some materials, predisposition for vernalization starts 30 days after germination, which corresponds to the end of the early rosette stage described earlier, peaks after 56 and again after 180 days (Müller-Stoll and Hartmann, 1959; reviewed in Chouard, 1960; Takimoto, 1985). Ecological studies indicate that effective induction of bolting requires a minimal rosette diameter of $9-12 \mathrm{~cm}$ (Gross, 1981; Kachi and Hirose, 1983; but also see Giménez et al., 2013 above). However, according to field observation by Marc T. J. Johnson, rosette size is not strictly correlated with bolting capability. In stressful environments, the minimal rosette sizes which allow shoot induction can be very small, but can reach more than $50 \mathrm{~cm}$ in productive environments.

Although the photoperiod during vernalization seems be unimportant (cf., Picard, 1965), Oenothera is typically vernalized for $7-14$ days at $4-8^{\circ} \mathrm{C}$ in a $10 \mathrm{~h}$ light/14 h dark cycle (cf., Clough et al., 2001). After vernalization, plants are transferred to large pots and returned to standard greenhouse conditions (long day, $16 \mathrm{~h}$ light/8 h dark). Unfortunately, some lines of Oe. biennis, Oe. villosa, and probably some Munzia strains, bolt erratically after this treatment. In a typical representative of this group, a line of the true European biennis (cf., Renner, 1942; Rostański,
1985), flower induction required an $11^{\circ} \mathrm{C}$ day $/ 3^{\circ} \mathrm{C}$ night treatment for more than 10 weeks, followed by a photoperiod longer than 12 h (e.g., Picard, 1965; for review see Chouard, 1960; Takimoto, 1985). We found that repeated, prolonged and harsh vernalization cycles together with transplanting into fresh substrate can induce flowering in such lines. However, these treatments are unreliable and prolong cultivation time significantly (Greiner, unpublished). Spray application of gibberellic acid generally induces bolting and subsequent flowering in most Oenotheras (Chouard, 1960; Takimoto, 1985; Reekie and Reekie, 1991; Greiner, unpublished). However, the "bolting resistant" line studied by Chouard and coworkers only responded by stem elongation and lignification, but neither bolted nor flowered (Chouard, 1960; Picard, 1965, 1967). The best alternative for the "bolting resistant" materials is hence to plant them into field no later than early May, when (artificial) vernalization is no longer required. This treatment is obligate and done so, the plants flower reliably (Renner, 1948; Chouard, 1960; and see below).

In summary, vernalization requirements for Oenothera can roughly be grouped into three categories: (i) strains/species with no or only very moderate demand for vernalization, (ii) material with "normal" vernalization requirements, and (iii) "bolting resistant" lines. Which strain belongs to which group is to some extent independent from the species and the optimal treatment for each line must be determined experimentally. Vernalization or planting to the field early in May does not harm genotypes without a vernalization requirement and is therefore recommended as standard operating procedure for genotypically diverse cultures.

\section{CROSS-POLLINATION AND SELFING, SEED HARVEST, PROCESSING, AND STORAGE}

Especially in section Oenothera, seed numbers per capsule are quite variable ranging from 180 to 500 (Hall et al., 1988; Harte, 1994; Dietrich et al., 1997). The seed yield per capsule is highest on the main stem, and also depends on the position at the stem. The first three to four flowers of a shoot produce significantly fewer seeds, and lower yields are also observed for the last 5-20 capsules (Stubbe, unpublished; Greiner, unpublished; Johnson, unpublished). For selfing of small-flowered, permanent translocation heterozygous strains, it is sufficient of remove the shoot tip and bag the remaining inflorescence. In those lines, if not anyway cleistogamous, anthers overgrow the stigma, which ensures pollination. Large-flowered, outcrossing, bivalentforming lines, where anthers are shorter than the style, benefit from additional hand-pollination. For cross-pollination, flowers with closed microsporangia should be emasculated 24 h before flower opening. Such flowers no longer display "vitreous" petals. Cleistogamous lines must be emasculated earlier. Typically, one stem displays three to five flowers in the suitable developmental stage. The remaining flowers below and flower buds above are removed. Cross-pollination is conducted when the flower is open, typically the following day. Direct pollination after emasculation is possible, but reduces yield, especially in cleistogamous material. The best pollen is obtained from flowers whose anthers already have released their pollen, one or half a day before flower opening. Since in Oenothera pollen grains are connected by viscin threads, 
special care must be taken to avoid unintentional pollen transfer. Cleaning tweezers and hands with $70 \% \mathrm{EtOH}$ and removing pollen threads from flowers before emasculation by washing or spraying with water are effective methods. Mature pollen frozen in liquid nitrogen and stored at $-80^{\circ} \mathrm{C}$ can remain fertile for at least three years, although this has not yet been investigated systematically, and fertilization success using such pollen has been variable so far (Greiner, unpublished). For bagging of inflorescences, we use pergamin bags (HERA Papierverarbeitung Puttrich GmbH \& Co KG, Germany, Cat. No. 720P40), that withstand rainfall and are thus well-suited for field experiments (cf., de Vries, 1913). Wet bags have to be exchanged soon after rainfall, to prevent mold from growing on the inflorescences. A third to half of the bag volume should be left empty, since stems will still grow by cell elongation after tip removal. Since lateral stems have a tendency to break from the rosette, especially in lines containing a C-genome, they must be tied to poles. When labels with a long wire are used (Hermann Meyer KG, Germany, Cat. No. 110130), bag closure, tying, and labeling can be conducted in a single step (cf., de Vries, 1913; and methods of the laboratories of Wilfried Stubbe, Reinhold G. Herrmann and Stephan Greiner).

The recognition of the best harvest time is not trivial. Ripe capsules turn brown and split. Among the alternating capsules on a stem, the basal ones can already disperse their seeds while the upper ones are still unripe. This makes an efficient harvest challenging, particularly in selfed plants with many capsules on a stems. Especially in the subsection Munzia, where shattering can be extreme, plants must be checked daily for ripe capsules during harvest. In addition, there is even a strong proximal/distal ripening gradient within the capsules of this subsection. Stems with ripe capsules can be dipped into 95\% EtOH and flamed before drying to reduce fungal contamination during subsequently germination (Sears and Klomparens, 1989; Sears, unpublished). Seeds must be dried for at least six weeks before processing for longterm storage. This can be done at room temperature between paperboards, or, in climate chambers at $15^{\circ} \mathrm{C}$ and $15 \%$ relative humidity. Subsequently, seeds should be frozen at $-20^{\circ} \mathrm{C}$. Seeds stored at room temperature fail to germinate after $3-5$ years (cf., de Vries, 1916). Storage at lower temperature $\left(4^{\circ} \mathrm{C}\right)$ prolongs seed life span significantly (cf., de Vries, 1913). A critical aspect of long-term seed storage is seed moisture. Seeds dried to $5 \%$ residual moisture (1 month in a dessicator with $\mathrm{CaCl}_{2}$ at room temperature) and stored in hermetically sealed packages (Dietrich, unpublished) remain viable for more than 25 years (Greiner, unpublished). Seeds buried in moist soil can remain viable for 80 years (Telewski and Zeevaart, 2002). Seed lifetime also depends on the nutrition status and vigor of the mother plant (de Vries, 1913).

\section{PEST CONTROL}

There is a general agreement in the literature about an enhanced resistance of Oenothera against diseases or pests (e.g., de Vries, 1913; Fieldsend and Morison, 1999; Deng et al., 2001). However, various insect pests, fungal and even intracellular bacterial pathogens were reported, which infect wild and cultivated evening primroses, including roots and seeds (e.g., de Vries, 1913; Hall et al., 1988; Sears and Klomparens, 1989; Venkatasubbaiah et al., 1991; Simpson etal., 1995; Deng etal., 2001; Johnson and Agrawal, 2005; Rakauskas, 2008; Agrawal et al., 2012; and references therein). Our experimental cultures of Oenothera, grown in Golm (Brandenburg, Germany) or Munich (Bavaria, Germany) were regularly infested with aphids and powdery mildew, more rarely downy mildew, white flies, and sap beetles. Besides that, invasion by scale insects has been reported for North America (Johnson, unpublished). Fungal infections by Botrytis occur especially at low temperatures in autumn. Young rosettes, but also flowering plants, are to some extent susceptible to thrips infection. In field cultures, damage by root voles was also observed. Infections by thrips, aphids, as well as downy mildew can quickly spread and cause irreversible damage. In our experience the pesticides mentioned below are widely tolerated by Oenothera, although sometimes flower abortion might result from Acetamiprid application $\left(5 \mathrm{mg} / \mathrm{m}^{2}\right)$ under certain environmental conditions. For tolerance of further insecticides see Agrawal et al. (2012).

The most suitable method of protection against thrips depends on the exact species that is responsible for the damage. Problematic are typical glasshouse thrips like Frankliniella occidentalis or Thrips tabaci, since they rapidly develop pesticide resistance and therefore cannot be controlled exclusively by insecticides. The most effective action is the proactive use of predatory mites. Amblyseius cucumeris (Katz Bio Tech AG, Germany, Cat. No. 4085) is applied to the leaves and kills the larvae of thrips. Another predator mite, Hypoaspis miles (Katz Bio Tech AG, Germany, Cat. No. 4140), is applied to the soil on planting and kills soildwelling stages. The biological control will become ineffective if temperatures are higher than $28^{\circ} \mathrm{C}$, which then may lead to massdevelopment of thrips. These can be controlled with Azadirachtin $\left(3 \mathrm{mg} / \mathrm{m}^{2}\right)$ or Spinosad $\left(27 \mathrm{mg} / \mathrm{m}^{2}\right)$ up to twice per year. Care must be taken because the predators are sensitive to many pesticides. The aphid species that commonly infests Oenothera in European greenhouse cultivation is Myzus persicae. This species can be controlled with Acetamiprid $\left(5 \mathrm{mg} / \mathrm{m}^{2}\right)$, Pirimicarb $\left(17.5 \mathrm{mg} / \mathrm{m}^{2}\right)$ or Pymetrozin $\left(18 \mathrm{mg} / \mathrm{m}^{2}\right)$. Acetamiprid and Pymetrozin must not be used on flowering Oenotheras that are being visited by bees. Furthermore, similar to greenhouse thrips, M. persicae rapidly develops pesticide resistance. Insecticides like rape seed oil or soap solutions that cause less resistance problems did not yield satisfactory result, although Oenothera tolerates these substances, if light intensities are less than $600 \mu \mathrm{mol} \mathrm{s}^{-1} \mathrm{~m}^{-2}$. Under suitable conditions (day length $>12 \mathrm{~h}$, temperatures $>15^{\circ} \mathrm{C}$ ), preventive biological control with aphid-parasitic Aphidius wasps like Aphidius colemani (Katz Bio Tech AG, Germany, Cat. No. 4050) should be applied. In North America, the situation can be quite different. Here, specialized aphids, including Macrosiphum gaurae and Aphis gaurae can attack Oenothera plants (Johnson, unpublished). White flies (Aleyrodidae) infect Oenothera species in the greenhouses without insect nets. As the chemical control of white flies is ineffective, preventive biological control with Encarsia formosa (Katz Bio Tech AG, Germany, Cat. No. 3050) needs to be implemented at the beginning of the season.

Fungal infection of Oenothera with Botrytis cinerea, Pythium, or downy mildew (Peronosporaceae) is best prevented by hygiene 
measures in the greenhouse, e.g., regular removal of dead plant material and cleaning of all surfaces including recycled pots with soap and water or a benzoic acid-based greenhouse disinfectant. Substrates for sowing or transferring Oenothera seedlings can be pretreated with Propamocarb $(0.906 \mathrm{mg} / \mathrm{l})$ to prevent damping off (Table 1). Downy mildew infections can be prevented by avoiding wet leaves, and controlled by Azoxystrobin $\left(25 \mathrm{mg} / \mathrm{m}^{2}\right)$. Powdery mildew (Erysiphaceae), in contrast, thrives at low air humidity and on older plant material. The infection rapidly spreads from older to younger plants when both are grown in the same greenhouse. Fungicides containing Tolylfluanid $\left(390 \mathrm{mg} / \mathrm{m}^{2}\right)$ or Azoxystrobin $\left(25 \mathrm{mg} / \mathrm{m}^{2}\right)$ kill powdery mildew but do not prevent reinfection. Powdery mildew rapidly becomes resistant to various fungicides. Application of sulfur spray was found to be ineffective and interferes with the biological thrips and aphid control (methods for Oenothera developed by Karin Köhl).

For further references on chemical pest control for various diseases, see, for example, Grignac (1988), Reeleder et al. (1996), Murphy et al. (2004), Johnson et al. (2009a), Agrawal et al. (2012), or Giménez et al. (2013). Many older pesticides are no longer registered and thus must not be used in greenhouses or fields, however. To obtain uninfected cultures in experimental fields, early clearing of the field in autumn and plot rotation is of particular importance (cf., de Vries, 1913; Reeleder, 1994; O'Connell et al., 2005).

Interestingly, some Oenothera strains homozygous for the Agenome, display a remarkable resistance against the major pests in experimental cultures, aphids and powdery mildew. This is even the case under very high infection pressures. On the other hand, strains containing a B-genome, as well as Munzia lines, are comparably susceptible to aphid or powdery mildew infections. Within the two groups genotypic variation is observed (Hall et al., 1988; Johnson and Agrawal, 2005; Agrawal et al., 2012; HerschGreen et al., 2012; Greiner, unpublished).

Oenothera displays broad resistance to pre- and post-emergence herbicides (Stringer et al., 1985; Richardson and West, 1986; Bates et al., 2013a,b). This might be utilized for effective weed control, especially in agronomics (Grignac, 1988; Roy et al., 1994; Honermeier et al., 2005; Ghasemnezhad and Honermeier, 2007). However, reports from the genetic literature are lacking so far.

\section{CULTIVATION IN FOIL GREENHOUSES AND EXPERIMENTAL FIELDS}

In the temperate climate zone of the northern hemisphere, Oenothera seeds are traditionally sown in January, seedlings are selected and potted in February, and transplanted to the field in April or May (e.g., de Vries, 1913; Gates, 1914; Schwemmle et al., 1938; Renner, 1948). Plants pre-cultivated in warm greenhouses that exclude ultraviolet radiation need to be hardened at the beginning of April, e.g., in a cold-frame with a shade-cloth, before they are transplanted to the field in the beginning of May (Linne von Berg, 1990). Requirement of fertilization depends on the nutrient content of the soil, which ought to be determined before plants are transplanted. The average planting distance is $30-35 \mathrm{~cm}$ (de Vries, 1913). In spite of its size, Oenothera is not very competitive in experimental field cultures (cf., Gross and Werner, 1982; but also see Johnson et al., 2008; Turley et al., 2013). Thus, weeds need to be controlled either manually or with a selective herbicide (see above). Plants start flowering in July and August. Crossings and self-pollination should be performed within six weeks (de Vries, 1913; Renner, 1917; Steiner and Stubbe, 1984). Seeds are harvested in September or October. Plants that flower later than the beginning of September rarely produce mature seeds, unless grown at lower latitudes. Non-bolted plants can be overwintered, although this may transfer pests and diseases to next year's field plots (de Vries, 1913; Johnson, 2007; and see above).

The schedule outlined above allows synchronization, flower induction, and seed maturation in large experiments with diverse genotypes within a growing season. Modern greenhouse facilities enable the compression of this schedule and allow sowing in March. Still the material must be planted into the field in the beginning of May, that it can undergo natural vernalization (Renner, 1948; Roy et al., 1994; but also see Johnson, 2007). Genotypically diverse cultures planted in June obligatorily require vernalization, but this still runs the risk that the "bolting resistant" lines fail to flower (see above). Material planted in June should be grown in containers to facilitate the transfer into the greenhouse in October/November for final seed maturation. Re-routing of field grown material or grafting of unripe stems regularly fails (Greiner, unpublished). However, Rossmann (1963) reports 90\% ripening success by placing half ripe stems in Knops's or Crone's nutrient solution.

As an alternative to field cultivation, Oenothera can be grown in pots in unheated polyethylene foil greenhouses (cf., Table 1). These greenhouses are substantially cheaper than glasshouses and prolong the season by 2-3 months, by allowing a $4-6$ week earlier start of the growth period and up to 2 months extension at the end of the season. Within the greenhouse, plants can be grown in pots, with minimal weeding. Plants are protected from the weather that can severely damage some "fragile" lines in the field. Rain protection makes the exchange of wet pollination bags unnecessary.

In both, the field and polyethylene foil greenhouses, additional treatments are required to induce flowering of Oe. grandiflora. The species has the ability to flower in long days when grown under standard greenhouse conditions (see above). However, when grown in field or in foil greenhouses in the North (e.g., Ann Arbour, MI, USA; Düsseldorf/Munich/Potsdam-Golm, Germany), Oe. grandiflora sets flower buds only as late as September, when plants experience the natural transition to short day (Steiner and Stubbe, 1984; Greiner, unpublished). Oe. grandiflora lines can be synchronized with other strains by a short-day regime of $10 \mathrm{~h}$ light/14 h dark, which is started when plants start bolting in long days and finished when flower buds are formed. Plants can then be planted in the field and will bloom in July and August (Steiner and Stubbe, 1984; Linne von Berg, 1990). However, such a treatment requires special growing facilities. Hence, alternatively one might grow Oe. grandiflora in a climate-controlled greenhouse in long days, in parallel to the other strains in the field/foil greenhouse. Another possibility for synchronization is to delay the complete field or foil greenhouse cultivation by late planting in June. However, special care must be taken to induce bolting of the strains not belonging to Oe. grandiflora and, most importantly, to allow adequate time for seed ripening late in the season (see above). In 
addition, Oe. grandiflora strains that bloom early in the field were reported (Steiner and Stubbe, 1984), which could be selected to simplify the crossing of multiple lines.

\section{AGRICULTURAL CULTIVATION}

Cultivars of subsection Oenothera are commercially grown as an oil seed crop for the production of gamma-linolenic acid (Russell, 1988; Simpson and Fieldsend, 1993; Deng et al., 2001; Ghasemnezhad and Honermeier, 2007). Due to their faster life cycle, some species in the subsection Munzia have been tested. These, however, displayed insufficient gamma-linoleic acid levels (Vilela et al., 2008).

A substantial amount of literature dealing with Oenothera crop management has accumulated, and a comprehensive review would be beyond the scope of this article. In brief, Oenothera is grown in temperate climates as winter and spring crop (Grignac, 1988; Simpson and Fieldsend, 1993; Deng et al., 2001). Spring cultivars, depending on the regional climate, can be drilled until mid-April. Plants start flowering in August and are harvested in October. Winter crops are started in August, overwinter as rosettes, flower in July and produce ripe seeds in September (Fieldsend and Morison, 1999; Fieldsend and Morison, 2000b; Honermeier et al., 2005). Winter crops require more effort in crop management, but allow an earlier harvest (Fieldsend and Morison, 2000a,b; O'Connell etal., 2005). In terms of yield or oil quality, no clear recommendation for spring and winter crops can be given. Among the investigated cultivars, spring crops tend to produce oil with a higher percentage of gamma-linoleic acid. Better overall oil content can be observed in winter-grown material, which has a higher biomass and potentially greater seed yields (Fieldsend and Morison, 1999; Fieldsend and Morison, 2000a,b; Honermeier et al., 2005). Nitrogen fertilization has minor effects on the yield and in any case should be applied moderately (Russell, 1988; Stobart and Simpson, 1997; Şekeroğlu and Özgüven, 2006; Ghasemnezhad and Honermeier, 2008). The most important factors for seed/oil yield and quality are harvesting time and method, as well as seasonal variation of environmental factors, e.g., growth temperature (Yaniv and Perl, 1987; Yaniv et al., 1989; Levy et al., 1993; Simpson and Fieldsend, 1993; Fieldsend and Morison, 2000a; Ghasemnezhad and Honermeier, 2007). Breeding goals for Oenothera include non-splitting capsules, high seed and oil yields, or high gamma-linoleic acid content. All of these were successfully combined, e.g., in the cultivar Rigel (Fieldsend, 2007).

\section{INTERSPECIFIC CROSSES, CROSS FERTILITY, AND FERTILITY OF HYBRID OFFSPRING}

Self-incompatibility is found to some extent in the entire genus Oenothera (Wagner et al., 2007), and was reported already very early, e.g., from Oe. organensis (subsection Emersonia; Emerson, 1938). However, self-incompatibility is less important in the genetically most relevant subsections. Self-incompatibility alleles have not been found in subsection Munzia (Dietrich, 1977) and they are rare in subsection Oenothera. Here, they occur in Oe. grandiflora (Stubbe and Raven, 1979b) and, according to work of Erich E. Steiner, in some lines of Oe. biennis. In this species they stabilize permanent translocation heterozygosity (for review see Cleland, 1972). As a rule, within the subsections of section
Oenothera, species can be hybridized freely, but offspring often express plastome-genome incompatibility. Besides chlorosis, these hybrids usually develop normally, but occasionally, sterility occurs or particular plastome-genome combinations result in severe growth retardation (e.g., Schwemmle et al., 1938; Schwemmle and Zintl, 1939; Stubbe, 1963; Cleland, 1972; Stubbe et al., 1978; Stubbe and Raven, 1979a; Stubbe, 1989; Harte, 1994; Stubbe and Steiner, 1999; and references therein). Hybrid incompatibility conferred by nuclear alleles is sometimes found between crosses of particular strains (e.g., Renner, 1917; Rossmann, 1963; Jean, 1984; Greiner, unpublished). In contrast to plastome-genome incompatibilities, these nuclear hybrid incompatibilities result from the genetic composition of the particular hybrid, which is often not connected with the taxonomic positions of the parents. Similar results are obtained, if species between the subsections of section Oenothera are hybridized. Although such hybrids are more difficult to obtain, and sometimes seed abortion is observed, inter-subsectional crosses generally produce offspring. The hypanthium length and/or the plastid (chloroplast) genotype are the most important, but not exclusive, barriers. Plastid genotype and hypanthium length facilitate realization of certain hybrids only in one crossing direction, i.e., the maternal parent must have a short hypanthium, allowing the paternal pollen tube to reach the egg cell, and/or must have a compatible plastid genotype in order for embryos to be able to develop. Other consequences of plastome-genome incompatibility include severe growth retardation, sterility or reduced fertility and/or meiotic irregularities in the resulting hybrids. To obtain particular hybrids, sometimes at least one parent must be equipped with a certain plastome type (Stubbe and Raven, 1979a). On the other hand, complete pollen sterility or seed abortion might be observed as a consequence of cytoplasmic exchanges between subsections (e.g., Kistner, 1955; Arnold, 1970). For references on the rich literature of intersubsectional crosses between sections Oenothera and Munzia, see Stubbe and Raven (1979a).

\section{VEGETATIVE PROPAGATION, INDUCTION OF POLYPLOIDY, AND MODIFIABILITY}

Vegetative propagation by stem cuttings is reported from ornamental strains of Oe. fruticosa (section Kneiffia; Clough et al., 2001). It is, however, rather ineffective in the subsection Munzia and Oenothera. In subsection Oenothera, new rosettes can be propagated from lateral rosette buds (de Vries, 1913). In addition, plants occasionally produce side rosettes. The signals triggering the production of such rosettes remain unclear (Greiner, unpublished). Also, young rosettes can be split and planted directly into moist soil. These plants will develop full rosettes again. Alternatively, they can be re-rooted in water or in a moist chamber first (Golczyk and Greiner, unpublished). Interestingly, some species within section Oenothera (especially Oe. humifusa and Oe. drummondii) often display root induction from a cut leaf surface, when leaf pieces are placed on wet filter paper for 1-2 weeks (Johnson, unpublished).

Species of subsections Oenothera and Munzia are exclusively diploid (Cleland, 1972; Dietrich, 1977; Dietrich et al., 1997), but effective protocols for the production of polyploid lines are available. Seeds or seedlings are placed on wet blotting paper 
containing colchicine, or alternatively rosettes are treated with colchicine shortly before bolting. In both cases, most surviving plants produce tetraploid offspring (Hecht, 1942; Stomps, 1942; Linnert, 1950; Renner and Hirmer, 1956). Subsequent treatments of tetraploid lines with colchicine can produce octo- or even hexadecaploid plants (Renner and Hirmer, 1956; Rossmann, unpublished). For non-permanent translocation heterozygotes, haploid lines are reported with a spontaneous frequency of $0.1-$ 0.2\% (Davis and Kulkarni, 1930; Harte, 1973). Additionally they can be induced by X-ray treatment (Linnert, 1950; Harte, 1972), or by performing wide interspecific crosses (e.g., Gates, 1929; Steiner, 1952; Schwemmle and Simson, 1956; Lee and Hecht, 1975; Harte, 1994; and references therein). Haploid material can be converted to double-haploid lines by colchicination (e.g., Oehlkers, 1940; Linnert, 1950; Lee and Hecht, 1975).

Plant habits and growth can be modified by abiotic factors. For example, if Oe. grandiflora is kept in small pots, plants stay substantially smaller and stress induces flowering extremely early. However, genotypic variation exists (Johnson, unpublished; Greiner, unpublished). A similar effect is observed, in Oe. elata, when small rosettes are treated with gibberellic acid (Greiner, unpublished). Application of uniconazole in Oe. fruticosa leads to flower induction in comparably small plants, whereas other growth regulators had no effect in this material (Clough et al., 2001).

Cultivation in constant light promotes flowering in plants of subsection Oenothera similar to long-day treatment, but can harm some genotypes. Grown in short days, however, plants produce more rosette leaves, which are smaller, but thicker and broader relative to long-day plants. Another contrast is that long-day rosettes have erect leaves, while short-day rosettes lay flat on the ground in a disk-like habit. Low temperatures promote this phenotype. Under such conditions, plants can be maintained for years in the greenhouse, since bolting is prevented. If rosettes, which failed to bolt after vernalization and long-day treatment, are maintained in a greenhouse under standard growing conditions $\left(18-22^{\circ} \mathrm{C}\right.$, long day), the plants will continue to produce new rosette leaves, but their stems will elongate and thicken, leading to a perched rosette after senescence of older leaves (Renner, 1948; Greiner, unpublished). This reassembles the phenotype obtained from application of gibberellic acid to the "bolting resistant" lines described above. For picture see (Picard, 1965, p. 262).

\section{GERMPLASM RESOURCES}

The laboratory of Stephan Greiner preserves a unique collection of Oenothera germplasms consisting of about 1000 accessions. The material mainly, but not exclusively, covers subsections Oenothera and Munzia, including wild races and laboratory stains. About 350 lines have been analyzed genetically in detail. Among them are hybrids of defined nuclear and plastid composition, chromosome translocation or plastome mutants. The collection was originally set up by Werner Dietrich and Wilfried Stubbe, later harbored by Reinhold G. Herrmann, and is extended since then. It represents most of the genetic work of Hugo de Vries, Otto Renner, Ralph E. Cleland, Wilfried Stubbe, Franz Schötz, Erich E. Steiner, Julius Schwemmle, Erick Haustein, Carl-Gerold Arnold, Adolph Hecht, Friedrich Oehlkers, Günther Rossmann, Reinhold G. Herrmann,
Barbara B. Sears, and other Oenothera scientists, and is the living reference collection for the taxonomy of subsection Oenothera by Werner Dietrich, Warren L. Wagner and Peter H. Raven (Dietrich et al., 1997), as well as the Munzia taxonomy of Werner Dietrich (Dietrich, 1977). A large and taxonomically diverse germplasm resource was collected by the laboratory of Marc T. J. Johnson (University of Toronto at Mississauga, ON, Canada). It harbors seeds of over 100 species from more than 1000 populations, with a special focus on the genus Oenothera, mostly Oe. biennis. Further Oenothera germplasm is available from the Ornamental Plant Germplasm Center (OPGC) at The Ohio State University (Columbus, OH, USA). The material is searchable by the USDA/ARS National Plant Germplasm System (Germplasm Resources Information Network, GRIN, www.ars-grin.gov). It includes material from Ralph E. Cleland, Wilfried Stubbe, Werner Dietrich, and Cornelia Harte, covering a substantial number of lines from the genetic literature, not only from the afore mentioned laboratories. Munzia species, commercial cultivars, and taxa from other Oenothera sections are present as well. Some of these lines are described as "historical records," but material provided to us from OPGC easily germinated. In addition, some groups currently working in the field have notable living collections. The largest reported collection of Oenothera germplasm so far was the result of a breeding program conducted by Scotia Pharmaceuticals Ltd., UK, through the end of the 1990s and contained about 2000 accessions of subsection Oenothera (Fieldsend, 2007).

\section{ACKNOWLEDGMENTS}

Drs Barbara B. Sears and Marc T. J. Johnson are acknowledged for critical reading, fruitful discussion, and sharing their experiences with Oenothera cultures, Dr Ralph Bock and Elena Ulbricht-Jones for helpful comments on the manuscript, Dr Wilfried Stubbe and Elisabeth Gerick for teaching Stephan Greiner to cultivate evening primroses. The authors are most grateful to Liliya Yaneva-Roder and Elisabeth Gerick for excellent technical assistance in our crossing programs, Ulrich Wissnet, Helga Kulka, Dirk Zerning, and Britta Hausmann for nursing our cultures in Munich and Golm for years, and Josef Bergstein for photography service. A special thanks goes to Reinhold G. Herrmann, who inspired and encouraged Stephan Greiner during his Ph.D. period for the Oenothera system. Work on Oenothera in the laboratory of the Stephan Greiner is supported by the Deutsche Forschungsgemeinschaft (DFG) and the Max Planck Society.

\section{REFERENCES}

Agrawal, A. A., Hastings, A. P., Johnson, M. T. J., Maron, J. L., and Salminen, J.-P. (2012). Insect herbivores drive real-time ecological and evolutionary change in plant populations. Science 338, 113-116. doi: 10.1126/science. 1225977

Arnold, C. G. (1970). Außerkaryotische Vererbung von Pollensterilität bei Oenothera. Theor. Appl. Genet. 40, 241-244. doi: 10.1007/BF00282032

Artz, D. R., Villagra, C. A., and Raguso, R. A. (2010). Spatiotemporal variation in the reproductive ecology of two parapatric subspecies of Oenothera cespitosa (Onagraceae). Am. J. Bot. 97, 1498-1510. doi: 10.3732/ajb.1000086

Baskin, C. C., and Baskin, J. M. (1994). Germination requirements of Oenothera biennis seeds during burial under natural seasonal temperature cycles. Can. J. Bot. 72, 779-782. doi: 10.1139/b94-098

Bates, A. N., Henry, G. M., and Mckenney, C. B. (2013a). Tolerance of Hooker's evening primrose transplants to preemergence herbicides. Hort. Technol. 23, 24-27. 
Bates, A. N., Henry, G. M., and Mckenney, C. B. (2013b). Tolerance of Hooker's evening primrose (Oenothera elata) transplants to postemergence herbicides. Weed Technol. 27, 401-404. doi: 10.1614/WT-D-12-00090.1

Brown, S. P., and Levin, D. A. (2011). Social dilemmas among supergenes: intragenomic sexual conflict and a selfing solution in Oenothera. Evolution 65, 3360-3367. doi: 10.1111/j.1558-5646.2011.01409.x

Burton, R. S., Pereira, R. J., and Barreto, F. S. (2013). Cytonuclear genomic interactions and hybrid breakdown. Annu. Rev. Ecol. Evol. Syst. 44, 281-302. doi 10.1146/annurev-ecolsys-110512-135758

Chiu, W.-L., and Sears, B. B. (1993). Plastome-genome interactions affect plastid transmission in Oenothera. Genetics 133, 989-997.

Chiu, W.-L., Stubbe, W., and Sears, B. B. (1988). Plastid inheritance in Oenothera: organelle genome modifies the extent of biparental plastid transmission. Curr. Genet. 13, 181-189. doi: 10.1007/BF00365653

Chouard, P. (1960). Vernalization and its relation to dormancy. Annu. Rev. Plant Physiol. 11, 191-238. doi: 10.1146/annurev.pp.11.060160.001203

Cleland, R. E. (1972). Oenothera-Cytogenetics and Evolution. London, New York: Academic Press Inc.

Clough, E. A., Cameron, A. C., Heins, R. D., and Carlson, W. H. (2001). Growth and development of Oenothera fruticosa is influenced by vernalization duration, photoperiod, forcing temperature, and plant growth regulators. J. Am. Soc. Hortic. Sci. 126, 269-274.

Davis, B. M. (1915). A method of obtaining complete germination of seeds in Oenothera and of recording the residue of sterile seed-like structures. Proc. Natl. Acad. Sci. U.S.A. 1, 360-363. doi: 10.1073/pnas.1.6.360

Davis, B. M., and Kulkarni, C. G. (1930). The cytology and genetics of a haploid sport from Oenothera franciscana. Genetics 15, 55-80.

de Gyves, E. M., Sparks, C. A., Fieldsend, A. F., Lazzeri, P., and Jones, H. D. (2001). High frequency of adventitious shoot regeneration from commercial cultivars of evening primrose (Oenothera spp.). Ann. Appl. Biol. 138, 329-332. doi: 10.1111/j.1744-7348.2001.tb00117.x

de Vries, H. (1901-1903). Die Mutationstheorie, Vols. I and II. Leipzig: von Veit.

de Vries, H. (1913). Gruppenweise Artbildung-Unter spezieller Berücksichtigung der Gattung Oenothera. Berlin: Gebrüder Borntraeger.

de Vries, H. (1915). Über künstliche Beschleunigung der Wasseraufnahme in Samen durch Druck. Biol. Cbl. 35, 161-171.

de Vries, H. (1916). Gute, harte, und leere Samen von Oenothera. Z. Indukt. Abstamm. Vererb. Lehre 16, 239-292. doi: 10.1007/BF01812791

de Vries, H. (1917). Keimungsversuche mit Nachtkerzensamen. Naturwissenschaften 5, 725-730. doi: 10.1007/BF02448048

Deng, Y.-C., Hua, H.-M., Li, J., and Lapinskas, P. (2001). Studies on the cultivation and uses of evening primrose (Oenothera spp.) in China. Econ. Bot. 55, 83-92. doi: $10.1007 / \mathrm{BF} 02864548$

Dietrich, W. (1977). The South American species of Oenothera sect. Oenothera (Raimannia, Renneria; Onagraceae). Ann. Missouri Bot. Gard. 64, 425-626. doi: $10.2307 / 2395257$

Dietrich, W., and Wagner, W. L. (1988). Systematics of Oenothera section Oenothera subsection Raimannia and subsection Nutantigemma (Onagraceae). Syst. Bot Monogr. 24, 1-91.

Dietrich, W., Wagner, W. L., and Raven, P. H. (1997). Systematics of Oenothera section Oenothera subsection Oenothera (Onagraceae). Syst. Bot. Monogr. 50, 1-234. doi: 10.2307/25027870

Doroszewski, A. (2007). Solar radiation as a factor influencing germination of seeds of Oenothera rubricaulis Klebahn. Pamietnik Pulawski 144, 55-69.

Emerson, S. H. (1938). The genetics of incompatible pollen tubes in Oenothera organensis. Genetics 23, 190-202.

Ensminger, P. A., and Ikuma, H. (1987a). Photoinduced seed germination of Oenothera biennis L.: I. General characteristics. Plant Physiol. 85, 879-884. doi: 10.1104/pp.85.4.879

Ensminger, P. A., and Ikuma, H. (1987b). Photoinduced seed germination of Oenothera biennis L.: II. Analysis of the photoinduction period. Plant Physiol. 85, 885-891. doi: 10.1104/pp.85.4.885

Ensminger, P. A., and Ikuma, H. (1988). Photoinduced seed germination of Oenothera biennis L.: III. Analysis of the postinduction period by means of temperature. Plant Physiol. 86, 475-481. doi: 10.1104/pp.86. 2.475

Evans, M. E. K., Hearn, D. J., Hahn, W. J., Spangle, J. M., and Venable, D. L. (2005). Climate and life-history evolution in evening primroses (Oenothera,
Onagraceae): a phylogenetic comparative analysis. Evolution 59, 1914-1927. doi: 10.1111/j.0014-3820.2005.tb01061.x

Evans, M. E. K., Hearn, D. J., Theiss, K. E., Cranston, K., Holsinger, K. E., and Donoghue, M. J. (2011). Extreme environments select for reproductive assurance: evidence from evening primroses (Oenothera). New Phytol. 191, 555-563. doi: 10.1111/j.1469-8137.2011.03697.x

Fieldsend, A. F. (2004). Low temperature effects on the growth of evening primrose (Oenothera spp.) rosettes. Acta Agron. Hung. 52, 19-28. doi: 10.1556/AAgr.52.2004.1.3

Fieldsend, A. F. (2007). "The impact of plant breeding on seed oil content and quality in evening primrose crops," in Proceedings of the Joint International Conference on Long-Term Experiments, May 31st-June 1st, Agricultural Research and Natural Resources, Debrecen-Nyírlugo, Hungary, 29-36.

Fieldsend, A. F., and Morison, J. I. L. (1999). Manipulating light capture and seed yield in winter and spring evening primrose (Oenothera spp.). Aspect. Appl. Biol. 55, 233-240.

Fieldsend, A. F., and Morison, J. I. L. (2000a). Climatic conditions during seed growth significantly influence oil content and quality in winter and spring evening primrose crops (Oenothera spp.). Ind. Crop. Prod. 12, 137-147. doi: 10.1016/S0926-6690(00)00049-2

Fieldsend, A. F., and Morison, J. I. L. (2000b). Contrasting growth and dry matter partitioning in winter and spring evening primrose crops (Oenothera spp.). Field Crop. Res. 68, 9-20. doi: 10.1016/S0378-4290(00)00104-0

Fujii, T., and Isikawa, S. (1961). The effects if tempterature after light-exposure on the germination of Oenothera seeds. Bot. Mag. Tokyo 74, 414-418.

Gates, R. R. (1914). Breeding experiments which show that hybridisation and mutation are independent phenomena. Z. Indukt. Abstamm. Vererb. Lehre 11, 209-279. doi: 10.1007/BF01704320

Gates, R. R. (1929). A haploid Oenothera. Nature 124, 948. doi: 10.1038/124948a0 Ghasemnezhad, A., and Honermeier, B. (2007). Seed yield, oil content and fatty acid composition of Oenothera biennis L. affected by harvest date and harvest method. Ind. Crop. Prod. 25, 274-281. doi: 10.1016/j.indcrop.2006.12.005

Ghasemnezhad, A., and Honermeier, B. (2008). Yield, oil constituents, and protein content of evening primrose (Oenothera biennis L.) seeds depending on harvest time, harvest method and nitrogen application. Ind. Crop. Prod. 28, 17-23. doi: 10.1016/j.indcrop.2007.12.006

Giménez, R., Sorlino, D. M., Bertero, H. D., and Ploschuk, E. L. (2013). Flowering regulation in the facultative biennial Oenothera biennis L.: environmental effects and their relation to growth rate. Ind. Crop. Prod. 44, 593-599. doi: 10.1016/j.indcrop.2012.09.017

Glick, R. E., and Sears, B. B. (1994). Genetically programmed chloroplast dedifferentiation as a consequence of plastome-genome incompatibility in Oenothera. Plant Physiol. 106, 367-373. doi: 10.1104/pp.106.1.367

Golczyk, H., Musiał, K., Rauwolf, U., Meurer, J., Herrmann, R. G., and Greiner, S. (2008). Meiotic events in Oenothera - a non-standard pattern of chromosome behaviour. Genome 51, 952-958. doi: 10.1139/G08-081

Greiner, S. (2012). "Plastome mutants of higher plants," in Genomics of Chloroplasts and Mitochondria, eds. R. Bock and V. Knoop (Dordrecht, Heidelberg, New York, London, Netherlands: Springer), 237-266. doi: 10.1007/978-94-007-29209_11

Greiner, S., and Bock, R. (2013). Tuning a ménage à trois: co-evolution and coadaptation of nuclear and organellar genomes in plants. BioEssays 35, 354-365. doi: 10.1002/bies.201200137

Greiner, S., Rauwolf, U., Meurer, J., and Herrmann, R. G. (2011). The role of plastids in plant speciation. Mol. Ecol. 20, 671-691. doi: 10.1111/j.1365294X.2010.04984.X

Greiner, S., Wang, X., Herrmann, R. G., Rauwolf, U., Mayer, K., Haberer, G., et al. (2008). The complete nucleotide sequences of the 5 genetically distinct plastid genomes of Oenothera, subsection Oenothera: II. A microevolutionary view using bioinformatics and formal genetic data. Mol. Biol. Evol. 25, 2019-2030. doi: 10.1093/molbev/msn 149

Grignac, P. (1988). Evening primrose cultivation. Oléagineux 43, 123-124.

Gross, K. L. (1981). Predictions of fate from rosette size in four "biennial" plant species: Verbascum thapsus, Oenothera biennis, Daucus carota, and Tragopogon dubius. Oecologia 48, 209-213. doi: 10.1007/BF00347966

Gross, K. L. (1985). Effects of irradiance and spectral quality on the germination of Verbascum thapsus L. and Oenothera biennis L. seeds. New Phytol. 101, 531-541. doi: 10.1111/j.1469-8137.1985.tb02858.x 
Gross, K. L., and Kromer, M. L. (1986). Seed weight effects on growth and reproduction in Oenothera biennis L. Bull. Torrey Bot. Club 113, 252-258. doi: $10.2307 / 2996364$

Gross, K. L., and Werner, P. A. (1982). Colonizing abilities of “biennial” plant species in relation to ground cover: implications for their distributions in a successional sere. Ecology 63, 921-931. doi: 10.2307/1937232

Hagemann, R. (2010). The foundation of extranuclear inheritance: plastid and mitochondrial genetics. Mol. Genet. Genom. 283, 199-209. doi: 10.1007/s00438010-0521-z

Hall, I. V., Steiner, E., Threadgill, P., and Jones, R. W. (1988). The biology of Canadian weeds. 84. Oenothera biennis L. Can. J. Plant Sci. 68, 163-173. doi: $10.4141 /$ cjps88-016

Harte, C. (1972). Auftreten von Mutationen bei Oenothera hookeri nach Behandlung des Pollens mit Meterwellen. Theor. Appl. Genet. 42, 297-305. doi: 10.1007/BF00277722

Harte, C. (1973). Haploide Pflanzen bei Oenothera. Biol. Zlb. 92, 361-364.

Harte, C. (1994). Oenothera-Contributions of a Plant to Biology. Berlin, Heidelberg, New York: Springer.

Hecht, A. (1942). Colchicine-induced tetraploidy in Oenothera. Proc. Indian Acad. Sci. 51, 87-93.

Hersch-Green, E. I., Myburg, H., and Johnson, M. T. J. (2012). Adaptive molecular evolution of a defence gene in sexual but not functionally asexual evening primroses. J. Evol. Biol. 25, 1576-1586. doi: 10.1111/j.1420-9101.2012. 02542.x

Honermeier, B., Ghasemnezhad, A., and Beiten, S. (2005). Effect of different autumn and spring sowing times on seed yield and seed quality of evening primrose (Oenothera biennis L.). J. Med. Spice Plants 4, 187-193.

Jean, R. (1984). The genetics of pollen lethality in the complex heterozygote Oenothera nuda. Biol. Zlb. 103, 515-527.

Johnson, M. (2010). The contribution of evening primrose (Oenothera biennis) to a modern synthesis of evolutionary ecology. Popul. Ecol. 53, 9-21. doi $10.1007 / \mathrm{s} 10144-010-0250-5$

Johnson, M. T. J. (2007). Genotype-by-environment interactions leads to variable selection on life-history strategy in common evening primrose (Oenothera biennis). J. Evol. Biol. 20, 190-200. doi: 10.1111/j.1420-9101.2006. 01201.x

Johnson, M. T. J., and Agrawal, A. A. (2005). Plant genotype and environment interact to shape a diverse arthropod community on evening primrose (Oenothera biennis). Ecology 86, 874-885. doi: 10.1890/04-1068

Johnson, M. T. J., Agrawal, A. A., Maron, J. L., and Salminen, J.-P. (2009a). Heritability, covariation and natural selection on 24 traits of common evening primrose Oenothera biennis from a field experiment. J. Evol. Biol. 22, 1295-1307. doi: 10.1111/j.1420-9101.2009.01747.x

Johnson, M. T. J., Smith, S. D., and Rausher, M. D. (2009b). Plant sex and the evolution of plant defenses against herbivores. Proc. Natl. Acad. Sci. U.S.A. 106 18079-18084. doi: 10.1073/pnas.0904695106

Johnson, M. T. J., Dinnage, R., Zhou, A. Y., and Hunter, M. D. (2008). Environmental variation has stronger effects than plant genotype on competition among plant species. J. Ecol. 96, 947-955. doi: 10.1111/j.1365-2745.2008.01410.x

Kachi, N., and Hirose, T. (1983). Bolting induction in Oenothera erythrosepala Borbás in relation to rosette size, vernalization, and photoperiod. Oecologia 60 6-9. doi: 10.1007/BF00379312

Kistner, G. (1955). Über plastidenbedingtes Absterben während der Embryoentwicklung einiger Oenotherenbastarde. Z. Indukt. Abstamm. Vererb. Lehre 86, 521-544. doi: 10.1007/BF00309739

Lee, L. P., and Hecht, A. (1975). Chloroplasts of monoploid and diploid Oenothera hookeri. Am. J. Bot. 62, 268-272.

Levy, A., Palevitch, D., and Ranen, C. (1993). Increasing gamma linolenic acid in evening primrose grown under hot temperatures by breeding early cultivars. Acta Hortic. 330, 219-225.

Linne von Berg, G. J. M. (1990). Die Lokalisation der Gene für Plastommutatur (pm) und die Selbstinkompatibilität (Si) in Sippen der Subsektion Euoenothera. Ph.D. thesis, Heinrich-Heine-Universität, Germany.

Linnert, G. (1950). Untersuchungen über die Cytologie polyploider Pflanzen: I. Chromosoma 3, 328-356. doi: 10.1007/BF00319483

Müller-Stoll, W. R., and Hartmann, W. (1959). "Vernalisationsphasen und Stoffwechselerscheinungen bei zweijährigen Pflanzen," in Proceedings of the 9th International Botanical Congress, August 19th-29th, Montral, Canada, 275-276.
Murphy, C. L., Mckenney, C. B., Auld, D. L., and Hopper, N. W. (2004). Field production of Texas native evening primrose (Oenothera spp.) as a source of gamma linolenic acid. Acta Hortic. 629, 283-288.

Nei, M., and Nozawa, M. (2011). Roles of mutation and selection in speciation: from Hugo de Vries to the modern genomic era. Genome Biol. Evol. 3, 812-829. doi: $10.1093 / \mathrm{gbe} / \mathrm{evr} 028$

Nightingale, J., and Baker, J. D. (1995). Improving germination of evening primrose seed. J. Herbs Spices Med. Plants 3, 75-78. doi: 10.1300/J044v03n01_09

O'Connell, M. N., Kethees, W. V., Fieldsend, A. F., and Cullum, F. J. (2005). Sources of infection and methods of control of Septoria oenotherae in evening primrose (Oenothera spp.). Acta Agron. Hung. 53, 385-391. doi: 10.1556/AAgr.53.2005.4.4

Oehlkers, F. (1940). Genetische und physiologische Untersuchungen zum Vitalitätsproblem. Z. Bot. 35, 271-297.

Picard, C. (1965). Contribution à la connaissance de la vernalization, de ses particularités et de sa signification chez Oenothera biennis L. var. sulfurea de Vries. Ann Sci. Nat. Bot. 6, 197-314.

Picard, C. (1967). Action du CCC et du B 995 sur la mise à fleur d'une plante bisannuelle, l'Oenothera biennis. Planta 74, 302-312. doi: 10.1007/BF00384850

Rakauskas, R. (2008). Species of Aphis inhabiting European Oenothera: their biology, morphology and systematics (Hemiptera: Aphididae). Cent. Eur. J. Biol. 3, 307319. doi: 10.2478/s11535-008-0020-y

Rauwolf, U., Golczyk, H., Meurer, J., Herrmann, R. G., and Greiner, S. (2008). Molecular marker systems for Oenothera genetics. Genetics 180, 1289-1306. doi: 10.1534/genetics.108.091249

Rauwolf, U., Greiner, S., Mráček, J., Rauwolf, M., Golczyk, H., Mohler, V., et al (2011). Uncoupling of sexual reproduction from homologous recombination in homozygous Oenothera species. Heredity 107, 87-94. doi: 10.1038/hdy.2010.171

Reekie, E. G., and Reekie, J. Y. C. (1991). The effect of reproduction on canopy structure, allocation and growth in Oenothera biennis. J. Ecol. 79, 1061-1071.

Reeleder, R. D. (1994). Factors affecting infection of evening primrose (Oenothera biennis) by Septoria oenotherae. Can. J. Plant Pathol. 16, 13-20. doi: 10.1080/07060669409500782

Reeleder, R. D., Monette, S., Roy, R. C., and Court, W. A. (1996). Dieback of evening primrose: characteristics of Septoria oenotherae, its interactions with Botrytis cinerea, and use of fungicides to manage disease. Can. J. Plant Pathol. 18, 261-268. doi: 10.1080/07060669609500622

Renner, O. (1917). Versuche über die gametische Konstitution der Oenotheren. $Z$. Indukt. Abstamm. Vererb. Lehre 18, 121-294. doi: 10.1007/BF01809624

Renner, O. (1942). Europäische Wildarten von Oenothera. Ber. Deutsch. Bot. Ges. 60, 448-466.

Renner, O. (1948). Über die Modifizierbarkeit der Oenotheren. Biol. Clb. 67, 52-60. Renner, O., and Hirmer, U. (1956). Zur Kenntnis von Oenothera: I. Über Oe. conferta n. sp. II. Über künstliche Polyploidie. Biol. Zlb. 75, 513-531.

Richardson, W. G., and West, T. M. (1986). Tolerance of evening primrose (Oenothera biennis) and borage (Borago officinalis) to pre-emergence herbicides. Ann. Appl. Biol. 108, 138-139.

Rossmann, G. (1963). Analyse der Oenothera coronifera Renner. Flora 153, 451-468. Rostański, K. (1985). Zur Gleiderung der Subsektion Oenothera (Sektion Oenothera, Oenothera L., Onagraceae). Feddes Repert. 96, 3-14.

Roy, R. C., White, P. H., More, A. F., Hendel, J. G., Pocs, R., and Court, W. A. (1994). Effect of transplanting date on the fatty acid composition, oil content and yield of evening primrose (Oenothera biennis L.) seed. Can. J. Plant Sci. 74, 129-131. doi: $10.4141 /$ cjps $94-023$

Russell, G. (1988). Physiological restraints on the economic viability of the evening primrose crop in eastern Scotland. Crop Res. (Hortic. Res.) 28, 25-33.

Schwemmle, A. (1961). Keimungsversuche auf genetischer Grundlage. 2. Genetsiche Konstitution und Keimgsverlauf. Flora 150, 274-293.

Schwemmle, J., Haustein, E., Sturm, A., and Binder, M. (1938). Genetische und zytologische Untersuchungen an Eu-Oenotheren: Teil I bis VI. Z. Indukt. Abstamm. Vererb. Lehre 75, 358-800. doi: 10.1007/BF01847620

Schwemmle, J., and Simson, R. (1956). Die Kreuzungen der Oenothera hookeri mit Arten aus der Sektion Raimannia. Flora 143, 165-200.

Schwemmle, J., and Zintl, M. (1939). Genetische und zytologische Untersuchungen an Eu-Oenotheren: Die Analyse der Oenothera argentinae. Z. Indukt. Abstamm. Vererb. Lehre 76, 353-410. doi: 10.1007/BF01740893

Sears, B. B., and Klomparens, K. L. (1989). Leaf tip cultures of the evening primrose allow stabel, aseptic culture of mycoplasma-like organism. Can. J. Plant Pathol. 11,343-348. doi: 10.1080/07060668909501077 
Şekeroğlu, N., and Özgüven, M. (2006). Effects of different nitrogen doses and row spacing applications on yield and quality of Oenothera biennis L. grown in irrigated lowland and unirrigated dryland conditions. Turk. J. Agric. For. 30, 125-135.

Simpson, M. J. A. (1994). A description and code of development of evening primrose (Oenothera ssp.). Ann. Appl. Biol. 125, 391-397. doi: 10.1111/j.17447348.1994.tb04979.x

Simpson, M. J. A., and Fieldsend, A. F. (1993). Evening primrose: harvest methods and timing. Acta Hortic. 331, 121-128.

Simpson, M. J. A., O’Connell, M. N., Stobart, R. M., and Cullum, F. J. (1995). Occurrence and viability of Septoria oenotherae in commercial seed samples of evening primrose. Plant Pathol. 44, 547-551. doi: 10.1111/j.1365-3059.1995.tb01676.x

Singh, S., Kaur, R., and Sharma, S. (2012). An updated review on the Oenothera genus. J. Chin. Integr. Med. 10, 717-725. doi: 10.3736/jcim20120701

Steiner, E. (1968). Dormant seed environment in relation to natural selection in Oenothera. Bull. Torrey Bot. Club 95, 140-155.

Steiner, E. E. (1952). The results of hybridization between Oenothera elata and certain South American Euoenotheras. Pap. Mich. Acad. Sci. Arts Lett. 38, 89-96.

Steiner, E. E., and Stubbe, W. (1984). A contribution to the population biology of Oenothera grandiflora L'Her. Am. J. Bot. 71, 1293-1301. doi: 10.2307/2443654

Stobart, R. M., and Simpson, M. J. A. (1997). "The effect of nitrogen rate on yield and oil content in evening primrose," in Domestication, Production and Utilization of New Crops, eds J. Smartt and N. Haq. (Southampton, UK: International Centre for Underutilised Crops), 282.

Stomps, T. J. (1942). Über die künstliche Herstellung von Oenothera Lamarckiana gigas de Vries. Ber. Deutsch. Bot. Ges. 60, 125-131.

Stringer, D., Parker, C., and Richardson, W. G. (1985). Tolerance of Oenothera biennis to various herbicide treatments. Test. Agrochem. Cultiv. 106, 124-125.

Stubbe, W. (1963). Extrem disharmonische Genom-Plastom-Kombinationen und väterliche Plastidenvererbung bei Oenothera. Z. Vererb. Lehre 94, 392-411. doi: 10.1007/BF00897596

Stubbe, W. (1989). Oenothera-an ideal system for studying the interaction of genome and plastome. Plant Mol. Biol. Rep. 7, 245-257. doi: 10.1007/BF02668633

Stubbe, W., Pietsch, B., and Kowallik, K. V. (1978). Cytologische Untersuchungen über väterliche Plastidenvererbung und plastomabhängige Degradation der Samenanlagen bei einem Oenothera-Bastard. Biol. Zlb. 97, 39-52.

Stubbe, W., and Raven, P. H. (1979a). A genetic contribution to the taxonomy of Oenothera sect. Oenothera (including subsection Euoenothera, Emersonia, Raimannia and Munzia). Plant Syst. Evol. 133, 39-59.

Stubbe, W., and Raven, P. H. (1979b). Genetic self-incompatibility in Oenothera subsect Euoenothera. Science 204, 327. doi: 10.1126/science.204. 4390.327

Stubbe, W., and Steiner, E. (1999). Inactivation of pollen and other effects of genome-plastome incompatibility in Oenothera. Plant Syst. Evol. 217, 259-277. doi: 10.1007/BF00984370

Takimoto, A. (1985). “Oenothera," in CRC Handbook of Flowering, ed. A. H. Halevy (Boca Raton, FL: CRC Press), 231-236.

Telewski, F. W., and Zeevaart, J. A. D. (2002). The 120-yr period for Dr. Beal's seed viability experiment. Am. J. Bot. 89, 1285-1288. doi: 10.3732/ajb.89.8.1285

Theiss, K. E., Holsinger, K. E., and Evans, M. E. K. (2010). Breeding system variation in 10 evening primroses (Oenothera sections Anogra and Kleinia; Onagraceae). Am. J. Bot. 97, 1031-1039. doi: 10.3732/ajb.0900260
Thomas, B., and Vince-Puce, D. (1997). Photoperiodism in Plants. Toronto: Academic Press, Inc.

Turley, N. E., Odell, W. C., Schaefer, H., Everwand, G., Crawley, M. J., and Johnson, M. T. J. (2013). Contemporary evolution of plant growth rate following experimental removal of herbivores. Am. Nat. 181, S21-S34. doi: 10.1086/ 668075

Venkatasubbaiah, P., Grand, L. F., and Dyke, C. G. V. (1991). A new species of Pestalotiopsis on Oenothera. Mycologia 83, 511-513.

Vilela, A., González-Paleo, L., Rondanini, D., and Ravetta, D. (2008). Biomass allocation patterns and reproductive output of four Oenothera L. accessions native to Argentina. Ind. Crop. Prod. 27, 249-256. doi: 10.1016/j.indcrop.2007.09.005

von Arx, M., Goyret, J., Davidowitz, G., and Raguso, R. A. (2012). Floral humidity as a reliable sensory cue for profitability assessment by nectar-foraging hawkmoths. Proc. Natl. Acad. Sci. U.S.A. 109, 9471-9476. doi: 10.1073/pnas.1121624109

Wagner, W., Krakos, K., and Hoch, P. C. (2013). Taxonomic changes in Oenothera sections Gaura and Calylophus (Onagraceae). PhytoKeys 28, 61-72. doi: 10.3897/phytokeys.28.6143

Wagner, W. L., Hoch, P.C., and Raven, P. H. (eds). (2007). Revised classification of the Onagraceae. Syst. Bot. Monogr. 83, 1-240.

Wees, D. (2004). Stratification and priming may improve seed germination of purple coneflower, blue-flag iris and evening primrose. Acta Hortic. 629, 391-395.

Wellensiek, S. (1965). Recent developments in vernalization. Acta Bot. Neerl. 14, 308-314. doi: 10.1111/j.1438-8677.1965.tb00196.x

Wilkins, H., and Anderson, N. O. (2007). "Creation of new flora productes. Annualization of perennials - horticultural and commercial significance," in Flower Breeding and Genetics. Issues Challenges and Oportunities for the 21th Century, ed. N. O. Anderson (Dordrecht, The Netherlands: Springer), 49-64.

Xu, Y.-G., Li, H.-Y., Wang, G.-H., and Hu, B.-Z. (2010). Study on the aseptic germination condition of Oenothera biennis L. seed. Med. Plant 1, 14-16

Yaniv, Z., and Perl, M. (1987). The effect of temperature on the fatty acid composition of evening primrose (Oenothera) seeds during their development, storage and germination. Acta Hortic. 215, 31-38.

Yaniv, Z., Ranen, C., Levy, A., and Palevitch, D. (1989). Effect of temperature on the fatty acid composition and yield of evening primrose (Oenothera lamarckiana) seeds. J. Exp. Bot. 40, 609-613. doi: 10.1093/jxb/40.5.609

Conflict of Interest Statement: The authors declare that the research was conducted in the absence of any commercial or financial relationships that could be construed as a potential conflict of interest.

Received: 09 January 2014; paper pending published: 22 January 2014; accepted: 27 January 2014; published online: 13 February 2014.

Citation: Greiner S and Köhl K (2014) Growing evening primroses (Oenothera). Front. Plant Sci. 5:38. doi: 10.3389/fpls.2014.00038

This article was submitted to Crop Science and Horticulture, a section of the journal Frontiers in Plant Science.

Copyright (c) 2014 Greiner and Köhl. This is an open-access article distributed under the terms of the Creative Commons Attribution License (CC BY). The use, distribution or reproduction in other forums is permitted, provided the original author(s) or licensor are credited and that the original publication in this journal is cited, in accordance with accepted academic practice. No use, distribution or reproduction is permitted which does not comply with these terms. 